\title{
Transmisi Memori dan Trauma dalam Mother Land Karya Dmetri Kakmi: Kajian Postmemory
}

\author{
Andri Fernanda \\ Universitas Bangka Belitung \\ andrifernanda92@yahoo.co.id
}

\begin{abstract}
Abstrak
Penelitian ini mengkaji proses kreatif sebuah karya postmemory dalam proses transmisi memori dari generasi pertama ke generasi selanjutnya dan melihat peran penting gender dalam proses transmisi serta melihat gender dalam karya tersebut. Tujuan penelitian adalah membongkar struktur transmisi memori traumatis Dmetri Kakmi dalam novel Mother Land dan melihat konstruksi gender terhadap kesan-kesan traumatis yang muncul di dalam karya tersebut. Peneliti menggunakan teori postmemory yang dicetuskan oleh Marianne Hirsch. Hasil penelitian ini yakni: 1) ada dua transmisi yang membentuk novel, yaitu transmisi familial dari keluarga sehingga hal itu memunculkan imajinasi serta transmisi afiliatif. Dalam proses transmisi, gender memainkan peran kepada siapa dan narasi apa yang diceritakan kepada postgeneration; 2) peran gender di dalam novel terlihat dari infantilized yang dilakukan terhadap kaum Yunani dan Hyper-masculinized yang dilakukan terhadap kaum Turki sebagai icon of destruction.
\end{abstract}

Kata Kunci: Postmemory, Trauma, Transmisi, Identifikasi, Gender

\begin{abstract}
This research is a study about the creative process of postmemory work in the memory transmitting process from the first generation to the next generation and the important role of gender in the transmission process, and the perspective of gender in postmemory's work. The purpose of this research is to expose Dmetri Kakmi's traumatic memory transmission structure in his novel "Motherland" and to take a look at genderization in traumatic impressions that emerged in his work. The researcher used postmemory theory initiated by Marianne Hirsch to perceive 1) the transmission memory and the role of gender in Dmetri Kakmi's "Motherland" novel; and 2) the genderization process in that novel, and the results of this research: 1) two transmission form Mother Land novel, familial transmission from the writer's family that led the writer to having an imagination of his late grandfather and affiliative transmission. In the transmission process, gender plays a key role in choosing who and what narration to be told to post-generation; 2) the gender roles in the "Mother land" novel can be found from such varied sources such as infantilized to the Greeks and byper-masculinized to the Turks as icon of destruction.
\end{abstract}

Keywords : Postmemory, Trauma, Tansmission, Identification, Gender.

\section{Pendahuluan}

Penelitian ini mengkaji proses kreatif sebuah karya postmemory dalam mentransmisikan memori (sebagian besar adalah memori traumatis) dan peran penting gender dalam proses transmisi serta bagaimana gender dikonstruksi dalam karya tersebut. Transmisi memori biasanya terjadi di dalam kehidupan keluarga dari orang tua ke anak, kakek atau nenek ke cucu dan lainnya, tetapi tidak menutup kemungkinan transmisi memori yang kuat juga bisa terjadi dari luar lingkungan keluarga. Manusia merupakan makhluk 
sosial yang berinteraksi dengan dunia luar inilah yang menjadikan memori memiliki kemungkinan dipindahkan inter-generasi dan intra-generasi. Di dalam karya postmemory, memori masa lalu merupakan fondasi dasar cerita dengan menggabungkan memory of others dan imajinasinya, post-generation seakan-akan membangun sebuah badan baru untuk memori masa lalu yang berada di gudang pikirannya. Menurut Silverman dalam Hirsch mengutip sebuah adegan dari Chris Marker Film Sans Soleil: "who says that time heals all wounds? It would be better to say that time heals everything except wounds. With time the hurt of separation loses its real limits, with time the desired body will soon disappear, and if the desired body has already ceased to exist for the other then what remains is a wound, disembodied (Hirsch, 2012: 174).

Ada beberapa faktor dalam pemindahan transmisi memori atau trauma, yaitu pentransmisi (first or second generation), penerima transmisi (post-generation), mediasi dan hubungan antarkeduanya seperti latar belakang bahkan jenis kelamin mereka. Gender dianggap memainkan peran penting untuk membuat memori traumatis menjadi tak tertahankan atau bahkan memori tersebut malah menjadi perisai bagi mereka. Memori yang diadopsi oleh postgeneration bukanlah sebuah pengalaman yang mereka rasakan langsung melainkan pengalaman milik orang lain dan kejadian itu pun sudah terjadi sebelum mereka dilahirkan, dengan kata lain mereka mengambil risiko dengan mengorbankan storage of memory mereka untuk diisi oleh memori orang lain. Bagi para penulis post- generation yang mengadopsi memori masa lalu keberpihakan terhadap suatu kelompok atau etnis akan sangat terlihat jelas di dalam karyanya. Karya yang ditulis oleh post-generation bisa dikatakan sebagai bentuk kerinduan terhadap masa lalu sekaligus bentuk klarifikasi yang dilakukan postgeneration terhadap wacana masa lalu yang menurutnya berbeda dan perlu ungkap.

Mother Land adalah sebuah novel yang ditulis oleh Dmetri Kakmi, seorang imigran Australia yang lahir di Turki yang memiliki etnis Yunani dan sekarang telah menjadi warga negara Australia. Mother Land bercerita tentang seorang anak kecil di pulau Bozcaada yang juga dikenal sebagai Bozca Pulau di Laut Aegean. Kisah di dalam novel ini mengambil latar cerita ketika penduduk Yunani menjadi sasaran intimidasi oleh pemerintah Turki. Pada awal cerita, novel ini menyajikan kehidupan tradisional Bozcaada. Masalah dimulai ketika tokoh utama mendapat kekerasan dan degradasi, sampai keluarganya dipaksa untuk bermigrasi ke Australia dan akhirnya menetap di sana. Setelah beberapa tahun kemudian, anak muda ini tumbuh menjadi seorang laki-laki dewasa dan dia memiliki rencana untuk kembali ke tanah kelahirannya untuk mengetahui dan berdamai dengan masa lalunya.

Peneliti menggunakan pendekatan postmemory untuk melihat transmisi traumatis dan bagaimana kesan traumatik tersebut terepresentasi dalam karya. Peneliti memilih sebuah karya sastra imigran Australia yang berasal dari Turki sebagai objek penelitian ini.

Postmemory menjelaskan tentang hubungan pos-generasi yang membawa trauma personal, 
kolektif, ataupun kultural dari mereka yang hidup pada masa lalu (generasi sebelumnya). Pengalaman tersebut tidak dialami langsung melainkan hanya dengan mengingat melalui cerita, foto, images, dan perilaku orang yang berada di sekitarnya ketika ia tumbuh, tetapi pengalaman ini ditransmisikan kepada mereka sangat dalam dan sangat afektif sehingga menjadikan memori tersebut seolah-olah memori miliknya sendiri. Postmemory terkoneksi ke masa lalu tidak hanya dengan recall tetapi dengan investasi imajinasi, proyeksi, dan kreasi. Memori yang ditransmisikan biasanya adalah pengalaman yang bersifat traumatik, karena kesan-kesan traumatik memang lebih dominan dan lebih terekam kuat bagi individu, kesan traumatik inilah yang kemudian ditransmisikan ke generasi selanjutnya. Dalam postmemory posisi identitas tidak begitu ditekankan, tetapi lebih kepada struktur generasional dari transmisi yang tertanam sangat signifikan dalam bentuk mediasi. Mediasi tersebut dipengaruhi oleh beberapa hal, Hirsch (2012:5) mengatakan "Koneksi postmemory pada masa lalu bukanlah semata-mata dimediasikan melalui mengingat kembali atau recalling, melainkan berasal dari tiga hal penting yaitu investasi imajinasi, proyeksi, dan kreasi."

Dalam postmemory sejarah dipandang sebagai salah satu cara dalam menyampaikan memori masa lalu terlepas dari kebenaran ilmiah dan objektivitas cerita tersebut. Sejarah merupakan sebuah memori kolektif terhadap kejadian besar yang diarsipkan, lalu memori tersebut terus menerus direpetisi, diceritakan kembali, ditubuhkan sebagai cara mengingat kejadian ter- sebut agar individu yang lain juga mengetahuinya, baik individu di generasi sezaman atau pun generasi setelahnya.

Mengambil dari Jann Asmann dan Aleida Assmann serta dengan melakukan penelitian, kemudian Hirsch merangkumnya menjadi dua bentuk transmisi memori, yaitu familial postmemory dan affiliative postmemory yang menjadi gambaran dalam menjelaskan trauma yang ditransmisikan. Memang keluarga berperan sebagai bagian yang penting dalam mentransmisikan memori, karena keluarga memiliki perwujudan praktis. Tetapi tidak menutup kemungkinan transmisi memori hanya berhasil dilakukan di keluarga saja, memori yang membekas ini kemudian menjadi arsip budaya, memori kolektif yang kemudian bisa ditransmisikan melalui sistem simbolik yang tidak lagi hanya dimediasi atau dinegosiasi melalui perwujudan praktis seperti dalam keluarga.

Tentu dalam melihat batas antara struktur respektif transmisi sebagai familial dan affiliative postmemory ini perlu merujuk pada identifikasi vertikal yang terjadi di dalam keluarga dari orang tua kepada anaknya dan identifikasi horizontal di mana anak tersebut berinteraksi dengan segala hal yang memiliki image trauma ataupun orang-orang yang memiliki memori tentang Holocaust di zamannya.

Identifikasi sendiri dipecah oleh Hirsch menjadi dua bentuk berdasarkan proses transmisi, yaitu identifikasi intergenerational dan intragenerational. Di sinilah proses yang sangat penting bagi postgeneration dalam memahami narasi masa lalu yang diterimanya, di mana identifikasi intergenerational adalah identifikasi yang dilakukan seorang anak 
kepada keluarganya yang hidup di generasi sebelumnya, sedangkan identifikasi intragenerasional adalah identifikasi sezaman, yaitu identifikasi yang dilakukan terhadap apa pun yang berkaitan dengan memori atau trauma yang ada di zamannya. Identifikasi intergenerational adalah identifikasi vertical, sedangkan identifikasi intragenerational bersifat lebih terbuka.

Dalam proses identifikasi, apa pun yang berhubungan dengan masa lalu menjadi mediasi yang penting. Narasi atau cerita lisan, bahkan tulisan bukan satu-satunya alat yang membentuk trauma postgeneration, karena ketika anak melakukan proses identifikasi, ia akan mencari trace terhadap apa pun yang bisa menjembataninya ke masa lalu, seperti foto keluarga, museum, barang-barang yang menyimpan kenangan masa lalu, bahkan sangat mungkin bagi anak melakukan returning journey atau perjalanan kembali ke tempat-tempat yang menyimpan tekateki masa lalu.

Di dalam proses transmisi anak diposisikan sebagai dua kategori, yaitu sebagai keturunan dan sebagai agen historis. Perbedaan gender pun mempengaruhi seseorang dalam mengonstruksi memori, anak perempuan merupakan penerima transmisi yang baik, selain cara mengingat perempuan lebih baik daripada lakilaki, hal lain yang juga menjadikan perempuan sebagai agen post-generation yang berpotensi karena posisinya yang selalu terepresi. Hal ini lebih dikenal sebagai "mother-daughter transmission", tetapi Hirsch melihat bahwa itu bukan merupakan satu-satunya transmisi yang kuat. Transmisi bisa terjadi bukan hanya dari ibu, tetapi juga dari ayah, bahkan tidak menutup kemungkinan transmisi yang kuat hingga membentuk trauma juga bisa tejadi di luar ruang lingkup keluarga.

Pada karya Holocaust tentunya akan ada figur-figur yang ditampilkan baik itu figur dari pelaku kejahatan (perpetrator) ataupun korban (victim), kemudian figur tersebut akan menunjukkan bagaimana hubungan antara pelaku kejahatan dan korban di dalam karya tersebut. Di dalam bukunya, Hirsch mengambil contoh karya Samuel Bak dan Judi Chicago di mana pelaku kejahatan pada masa Holocaust selalu digambarkan yang paling berkuasa, sedangkan pada korban selalu ditampilkan sebagai yang tidak berdaya atau diinfantilisasi. Hirsch memberikan pernyataan yang jelas bahwa gender role akan sangat jelas terlihat perbedaannya, antara pelaku kejahatan dan korban.

"... but the gender roles are clearly differentiated: perpetrators, whether Nazi or Israel, are male, whereas victims, whether Jewish or Palestinian, are children of grieving mothers." (Hirsch, 2012:144)

Selain itu perbedaan antara susunan biologis tubuh dan jenis kelamin antara laki-laki dan perempuan juga memperlihatkan kekejaman dengan cara yang berbeda pula. Contohnya, wanita memang lebih sedikit mengalami kekerasan fisik seperti dipukuli dan dianiaya dibanding lakilaki, tetapi pelecehan seksual dilakukan lebih banyak terhadap wanita meskipun mungkin ada beberapa laki-laki yang mengalami kekerasan seksual. Di sinilah Hirsch melihat adanya perbedaan dalam mempertahankan hidup antara laki-laki dan perempuan di dalam karya-karya Holocaust. 


\section{Transmisi Familial}

Memori kakek Dmitro masih tetap hidup di dalam pikiran Kakmi meskipun secara fisik kakek Dmitro sudah mati. Ini menunjukkan bahwa memori kakek Dmitro yang diadopsi oleh Kakmi pun tidak ditransmisikan langsung oleh sang kakek Dmitro tetapi bisa melalui neneknya sebagai agen generasi pertama yang masih hidup ataupun dari orang tuanya yang merupakan generasi kedua.

"That's grandfather Dimitro speaking. Listen because be knows a lot, and he does not take kindly to repeating himself. I am sitting with him on the peak of saint Elias's bill bebind our country house, gazing across the narrows to the mainland." (Kakmi, 2009:13)

Pada bagian ini, Dmetri kecil menceritakan bagaimana dia bertemu dengan kakeknya, dan kakeknya tersebut bercerita banyak tentang tanah kelahirannya. Kakek yang saat itu bersama Dmetri bukanlah kakek Kakmi yang sebenarnya, melainkan imajinasi dari Dmetri. Seperti yang dikatakan Kakmi di dalam wawancara bersama penulis,

He (Grandfather Dmitro) die before I born, but wether its true or not I don't know but he appear to me and he teached me how to read and write. (Kakmi:2016)

Sosok kakek Dmitro dihadirkan dalam bentuk "spirit" yang tidak lain hal tersebut adalah investasi imajinasi yang dimiliki oleh Dmetri Kakmi. Secara rasional, itu adalah hal yang tidak mungkin terjadi dan berada di luar nalar manusia. Di sinilah Dmetri mengalami kebingungan terhadap dirinya (self) dikarenakan oleh efek memori masa lalu yang diadopsinya dan memori tersebut sudah menubuhkan dirinya, di mana dia tidak bisa membedakan mana yang nyata (real) dan mana yang tidak nyata (fantasize). Hal ini sama dengan apa yang disebut Hirsch sebagai Ghost of Home. Memori dari generasi pertama telah memberikan pengaruh yang sangat kuat, narasi keluarga berada pada lapisan dasar atau pondaso yang kemudian memberikan efek membayangi (overshadow) terhadap dirinya. Hal itu terfragmentasi dan secara tidak sadar menciptakan investasi imajinasi dan proyeksi terhadap sosok kakek Dmitro.

"I close my eyes and think of Grandfather Dmitro to calm me down. He inherited this house from his parents. They left it to bim when the last sultan was still living in Stanbul. When he was a young man, Grandfather lost his first wife and two danghters to typhoid. He was so grief-stricken that, overnight, he lost his sight. Because there was no one to care for him, he was shipped off to the nuns on Tinos Island." (Kakmi, 2009:28)

Dari kutipan tersebut diketahui bahwa kakek dari Dmetri Kakmi memang hidup pada saat Kekaisaran Ottoman atau dikenal juga dengan Kesultanan Utsmaniyah yang sekarang menjadi Negara Turki Modern yang bertanggung jawab atas pembunuhan massal atau dikenal dengan Genosida Armenia yang terjadi selama dan setelah perang dunia I.

Tidak hanya kakek dari pihak ayah, tetapi juga kakek dari pihak ibu ikut berpartisipasi dalam mentransmisikan memori masa lalu dalam ruang keluarga. Terdapat beberapa bagian di mana terlihat bahwa ada memori tentang masa lalu yang diterima oleh Kakmi walaupun porsinya lebih banyak dengan kakek Dmitro.

"Grandfather Elias is a gentleman. He returned from World War One with shattered eardrums 
and a gammy leg. I don't know which leg because I've never seen bim walk. He's always sitting down. He is twenty years older than grandmother." (Kakmi, 2009:86)

Luka pada tubuh adalah salah satu ben-

tuk mediasi bagi post-generation yang menjadi faktor penting dalam berhasilnya proses penerimaan transmisi memori. Melalui luka pada tubuh, agen post-generation bisa langsung melakukan identifikasi terhadap luka dengan mengorelasikan pada narasi yang diterimanya. Bisa dikatakan bahwa luka masuk dalam bentuk returning journey di mana luka adalah cenderamata dari masa lalu yang digunakan agen post-generation membantu agen post-generation dalam menjembatani masa lalu dan masa kini. Returning journey merupakan salah satu bagian yang sangat crucial bagi agen post-generation dalam memahami memori yang diadopsinya.

\section{Transmisi Affilial}

Tidak hanya berhenti di situ, terdapat beberapa transmisi affilial yang terdapat di dalam novel Mother Land. Secara sadar atau tidak Dmetri Kakmi telah memberikan penjelasan langsung bagaimana transmisi Affilial terjadi sewaktu ia masih kecil.

Because you're not a Turk, may the bread you eat be poisonous.' It's a shame because until then, I thought she was going to be a good teacher, this blonde tall-as-a-popular woman. A bit pallid and thin-lipped, but you can't blame her for that. It stayed with me, what she said. (Kakmi, 2009:34)

Sekolah merupakan sesuatu yang berada di luar ruang lingkup keluarga tetapi mempunyai pengaruh yang cukup besar dalam mendominasi cara berfikir seseorang karena sekolah mendapatkan legitimasi sebagai tempat yang dipercayai oleh masyarakat sebagai tempat menimba ilmu dalam memperoleh pendidikan dan segala informasi yang ada. Dari pernyataan di atas terlihat bagaimana besar kekuatan transmisi memori secara afilial yang ada di sekolah sehingga kata-kata tersebut terus membekas di dalam pikiran Dmitri hingga kini.

\section{Hypermasculinized terhadap Turki}

Image Turki yang ditampilkan sebagai perpetrator muncul dalam bentuk perlakuan yang dilakukan Turki terhadap kaum Yunani baik secara eksplisit seperti kekerasan fisik yang dilakukan maupun implisit seperti ketidakadilan peraturanperaturan yang dibuat sehingga efek dari peraturan tersebut berat sebelah. Turki memiliki banyak keuntungan dari peraturan tersebut, sedangkan Yunani terpinggirkan. Semua ini terus direpitisi dengan pola yang sama oleh pengarang di dalam novelnya.

"I've told you a bundred times. Don't you listen? The Government's turned the island into an open prison.' His long fingers book the tip sharp nose when he plucks the cigarette from his lips. Do you know what that means?' he ask. I nod. 'Well, that's what Tenedos is now - an open prison.' (Kakmi, 2008:24)

Dari kutipan di atas terlihat kaum Turki yang memiliki kekuasaan hingga kaum Yunani tidak bisa berbuat apa-apa terhadap kebijakankebijakan yang ada. Bahkan kota kelahirannya diumpamakan sebagai penjara terbuka, karena mereka memang tinggal dan hidup berkeluarga di sana, tetapi mereka tidak bebas begitu saja, seperti penyitaan properti yang dimiliki oleh kaum Yunani, bisnis-bisnis kaum Yunani ditutup, dan anak-anak Yunani wajib menghadiri sekolah Tur- 
ki. Dengan kata lain, kaum Turki bukan hanya sekedar ingin menguasai tanah tersebut, tetapi lebih jauh lagi, mereka ingin menggeneralisasi orang-orang yang hidup di sana hanya kaum mereka saja. Dengan cara yang frontal yaitu dengan mendeportasi kaum Yunani maupun dengan cara yang halus seperti mengharuskan anak-anak dari keturunan Yunani untuk belajar di sekolah Turki sehingga cara berpikir mereka akan dibentuk di sana. Hal ini dipandang sebagai cara yang sangat efektif untuk mengaburkan identitas sang anak sebagai Yunani, dengan kata lain mereka ingin mengubah jati diri anakanak Yunani menjadi Turki. Hal itu diperkuat dengan adanya kewenangan bahwa hanya kaum Yunani yang memiliki kewarganegaraan Turkilah yang boleh menetap dan tinggal lebih lama di sana.

Thousands of Greeks were deported, she continues. Once again, only Greeks with Turkish citizenship were allowed to remain. The Government confiscated properties and closed down bussines that belonged to Greeks. Ethnic school ceased to exist and it became compulsory for Greek children to attend Turkish schools. (Kakmi, 2008:45)

Dari kutipan di atas ditampilkan bagaimana kaum Turki sangat mendominasi. Bentuk dominasi kaum Turki ditampilkan dalam peraturan-peraturan yang dibuat di dalam negara. Bentuk kekuasaan yang dianut sangat berat sebelah dengan lebih banyak memberikan keuntungan terhadap kaum Turki sedangkan kaum Yunani hanya mempunyai dua pilihan, yaitu pindah ke negara lain atau menetap tetapi dengan risiko harus menaati peraturan-peraturan yang menguntungkan kaum Turki. Hal tersebut diungkapkan beberapa kali di dalam novel.

"For the live of me, though, I do not know how Sinan, a man who was born the year after we left Turkey, fits into my paralysis of the soul. As Australians say, I did not know him from a bar of soap. Unable to believe that he, a Turk, no less, was merely acting out of the kindness of his heart, I indulge in all manner of paranoid fantasies. One minute he is the kind and thoughfull friend, the next a government agent sent to spy on me." (Kakmi, 2008:241)

Dalam artian para kaum Yunani menganggap bahwa tidak ada dari mereka (Turki) yang berlaku baik dengan Yunani. Obsesi kaum Turki untuk mendominasi wilayah terlihat dari doktrin-doktrin yang dimasukkan kepada anak-anak kecil hingga pada ruang lingkup sekolah. Hal ini sebagai salah satu cara mereka dalam membentuk pola pikir postgeneration Yunani untuk mengaburkan jati diri mereka sebagai Yunani.

At the end of the song, all students rise and shout, 'long live ataturk's republic!' except me. And where is your mind, Pray tell? I snap out of my reverie. ..... she takes my ear lobe between her thumb and forefinger and pulls me up. Her fingernails are red talons. They dig into my flesh. 'put out your hand.'........... from the corner of my eye, I see the big thick ruler in the teacher's hand slice the air like the wing of an albatross. The flat of the wood connect with my head across my left ear. (Kakmi, 2008:59)

Pada kutipan di atas bisa dilihat bagaimana Dimitri kecil yang tidak ikut serta berdiri dan hanya diam saja mendapatkan perlakuan yang sangat di luar dugaan dari gurunya. Sosok gurunya yang seharusnya mengayomi, mendidik, dan mengajar malah menjadi sosok yang menakutkan bagi anak muridnya. Kakmi menampilkan situasi yang sangat jelas di mana kaum Yunani diinfantilisasi sebagai sosok 
murif yang lugu, yang mengalami false sense of intimacy, sebagai sosok yang polos tanpa dosa, sedangkan Turki diwakili oleh sosok guru, sosok yang berkuasa yang memiliki power yaitu pengetahuan sehingga menjadikannya berada pada posisi tertinggi. Pada bagian ini, posisi guru ditampilkan sebagai sosok yang bypermasculinized karena di dalam kelas tidak ada yang bisa membantah apa yang dikatakan guru, sehingga apa pun yang dilakukan oleh guru dianggap sebuah kebenaran bahkan saat guru melakukan kekerasan kepada Dimitri yang tidak ikut berdiri dan berkata long live ataturk's republic tidak mendapat penolakan dari murid lainnya. Murid lain yang menyaksikan kejadian tersebut hanya diam, diam bukan berarti mereka setuju, mungkin mereka menolak apa yang dilakukan guru terhadap Dmitri tetapi mereka tidak bisa berbuat apa-apa karena mereka pada posisi yang tidak berdaya. Guru yang memiliki posisi tertinggi juga menjadi lambang icon of destruction yang sebisa mungkin jangan sampai terlibat masalah dengannya, sehingga ketika mereka mencoba membantu Dimitri yang mendapatkan perlakuan kasar secara tidak langsung mereka melakukan bentuk perlawanan terhadap guru.

\section{Feminized terhadap kaum Yunani}

Di dalam bukunya Hirsch mengatakan bahwa strategi cropping merupakan strategi yang paling sering digunakan para penulis-penulis post -generation di dalam karyanya. Biasanya para seniman post-generation melakukan universalisasi terhadap korban di dalam kejadian besar tersebut sebagai orang-orang yang tidak bersalah.
Di dalam novelnya, tentu Kakmi juga melakukan strategi yang sama dalam membentuk wacana tentang kaum Turki dan kaum Yunani seperti halnya strategi yang dilakukan para seniman-seniman postgeneration lainnya. Strategi cropping merupakan strategi yang dilakukan oleh post-generation di mana pengarang menonjolkan tokoh ataupun situasi tertentu dan menghilangkan beberapa dalam menciptakan stereotype. Tentu, ada keberpihakan dan cara pandang pengarang di dalam suatu karya dari dua kelompok yang berbeda. Keberpihakan pengarang terhadap satu kelompok akan terlihat dari narasi yang ditonjolkan. Seperti pada kasus lukisan Rebecca Shope yang menjadi sampul The Jewish Holocaust for Beginners di mana cropping dilakukan terhadap Jerman sebagai perpetrator atau pelaku kejahatan dalam Holocaust, fokus gambar menitikberatkan kepada anak laki-laki yang mengangkat tangan sebagai gambaran korban yang tidak bersalah, sedangkan perpetrator dibuat sangat maskulin dengan senapan sehingga lebih perbedaan antara evil dan innocent sangat menonjol. Hal yang sama juga dilakukan oleh Kakmi dengan cara yang berbeda, bila pada kasus di atas cropping digunakan di dalam lukisan dengan cara menonjolkan sosok anak sebagai korban yang ditodong yang secara tidak langsung sudut pandang diambil dari Jerman sebagai perpetrator, pada Kakmi cropping dilakukan dengan cara memperlihatkan narasi-narasi tentang kejahatan yang dilakukan oleh kaum Turki terhadap kaum Yunani, sedangkan narasi tentang kebaikan yang dilakukan oleh kaum Turki terhadap kaum Yunani hampir tidak ditampilkan atau dihilangkan. Salah satu narasi yang memperlihatkan bahwa tidak semua kaum Turki itu adalah perpe- 
trator terdapat pada kutipan berikut.

"For the live of me, though, I do not know how Sinan, a man who was born the year after we left Turkey, fits into my paralysis of the soul. As Australians say, I did not know bim from a bar of soap. Unable to believe that he, a Turk, no less, was merely acting out of the kindness of his heart, I indulge in all manner of paranoid fantasies. One minute he is the kind and thoughfull friend, the next a government agent sent to spy on me." (Kakmi, 2008:241)

Sinan merupakan seorang teman keturunan Turki yang menemaninya dalam perjalanan kembali ke tanah kelahirannya. Sinan selain sebagai teman perjalanannya sekaligus menjadi penuntun dan penerjemahnya saat berada di tanah kelahirannya. Seperti yang diketahui bahwa tanah kelahirannya telah berubah semenjak Kakmi pindah ke Australia. Terlihat bagaimana pandangan Kakmi terhadap Sinan yang merepresentasikan bagaimana cara pandangnya terhadap kaum Turki. Sinan sebagai seorang teman berdarah Turki yang menemani perjalanannya kembali ke tanah kelahiran dianggap sebagai teman yang baik dan bijaksana yang memberikannya dukungan, baik dukungan emosional maupun dukungan dalam bentuk tindakan, tetapi tetap saja dalam prasangka baik Kakmi terhadap Sinan yang merupakan keturunan Turki tetap ada tersulut prasangka buruk terhadapnya di mana dia merasa bahwa dia sedang ditemani oleh mata-mata pemerintah Turki. Hal ini terjadi karena cara berpikir Kakmi terhadap Turki memang sudah dibentuk sejak kecil dari adopsi keluarga, yang kemudian lingkungannya juga ikut mendukung hal terserbut sehingga seakanakan telah terkonsep di dalam pikirannya bahwa semua kaum Turki merupakan perpetrator atau pelaku kejahatan, tidak ada kaum Turki yang berposisi sebagai bystander (orang yang tidak ikut dalam pembantaian atau tidak melakukan apa-apa). Generalisasi yang dilakukan Kakmi terhadap Sinan sebagai keturunan Turki ini pun disesali olehnya. Sekali lagi terjadi proses bargaining di dalam dirinya, bahwa dia sadar atas apa yang dilakukannya itu salah tetapi di sisi lain dia tidak bisa menghilangkan prasangka-prasangka buruk terhadap Kakmi.

Kakmi sadar bahwa dia tidak adil atas apa yang ia pikirkan terhadap Sinan. Tetapi pikiran itu muncul dengan sendirinya, dengan kata lain pikiran Kakmi terhadap Sinan merupakan representasi dari alam bawah sadarnya. Inilah yang dikatakan trauma dari generasi pertama membayangi memori sendiri, tidak jarang apa yang dimiliki oleh memori sendiri bertentangan dengan apa yang ditransmisikan dari generasi sebelumnya. Seperti kasus Kakmi dengan Sinan, ia mengalami langsung dan berinteraksi langsung dengan seorang keturunan Turki yang baik dan banyak memberikan pertolongan terhadapnya, yang hal tersebut tentunya bertentangan dengan apa yang diterimanya sejak kecil bahwa semua kaum Turki itu jahat, sehingga walaupun di satu sisi Kakmi mengakui bahwa Sinan itu adalah seorang teman yang baik, tetapi di sisi lain dia juga mencurigai Sinan dan hal itu muncul dalam bentuk penyesalan. Tetapi penyesalan tersebut musnah ketika Kakmi mencoba menarik Sinan ke masa lalu, masa di mana pembantaian dilakukan oleh kaum Turki terhadap kaum Yunani.

"How could there be such a disconnection be- 
tween past and present? Am I honestly expected to believe that an educated man can go through university and not know what his country had done to us?" (Kakmi, 2008:252)

Terlihat bagaimana rasa kesal Kakmi diperlihatkan terhadap Sinan ketika Sinan mengatakan bahwa ia tidak mengetahui bahwa Turki dan Yunani mempunyai masa yang kelam saat perang dan pascaperang yang membuat orang-orang Yunani meninggalkan rumah mereka dan mengungsi karena adanya aturan-aturan yang merugikan kaum Yunani. Secara tidak langsung, Kakmi melakukan feminization terhadap kaum Yunani. Pada kondisi ini, Kakmi memosisikan dirinya sebagai korban dan saksi sekaligus. Kaum Yunani yang menerima memori tentang masa lalu di mana perang terjadi antara kaum Turki dan Yunani, saat perang dunia pertama. Hal itu diperkuat dengan memorinya sendiri saat dia masih tinggal di Bozcaada pada tahun 1961 di mana masih ada jarak yang sangat lebar antara Turki dan Yunani, meskipun pada saat itu perang sudah berakhir tetapi perang dingin antara dua kaum yang berbeda masih dirasakan.

Feminized terhadap Yunani sebagai korban juga ditampilkan secara eksplisit dan vulgar di dalam novelnya, dengan mencampurkan postmemory dan rememory di dalam Mother Land, Kakmi menciptakan narasi di dalam novel terlihat lebih nyata dan meyakinkan. Hal ini terlihat bagaimana memori tentang masa lalu (memori dari generasi pertama) dimunculkan terlebih dahulu yang kemudian dikorelasikan dengan kenangan yang dialaminya bersama keluarga saat ia masih kecil,

"On the day of the disaster, our usually placid neighbourbood, where Greeks lived side by side with Turks, was in turmoil. Soldiers went door to door, shooting Greeks, looting, setting fire to houses.” (Kakmi,2008:219)

Vulgaritas dan kekejaman dari kaum Turki terhadap kaum Yunani dimunculkan dalam narasi generasi kedua. Pada kutipan tersebut terlihat seakan-akan Yunani adalah hama yang harus dibasmi dan nyawa seorang Yunani tidak berarti. Barangbarang mereka dijarah dan rumah mereka dibakar, mereka ditembak mati dan tidak diperlihatkan sama sekali bentuk perlawanan yang dilakukan kaum Yunani, ini yang kemudian diperlihatkan bahwa Yunani berada pada posisi powerless dan terus direpetisi di dalam novelnya melalui narasi-narasi dari generasi pertama dan kedua maupun dari pengalaman Kakmi sendiri yang kemudian memberikan label innocent terhadap Yunani. Ini yang dikatakan oleh Hirsh sebagai strategi cropping, dengan menonjolkan Yunani sebagai korban atas kejahatan sejarah yang pernah dilakukan oleh Turki membuat universalisasi terhadap dua kaum tersebut, khususnya penekanan terhadap kaum Yunani sebagai victim dengan menghilangkan beberapa narasi seperti adanya kaum Turki yang membantu kaum Yunani ataupun ada kaum Yunani yang melakukan kejahatan pada kaum Turki.

Kaum Yunani yang diinfantilisasi sebagai korban diperkuat dengan keadaan di mana Kakmi dan keluarganya harus meninggalkan tanah kelahirannya.

My mother instantly flares up. 'we did not 
Poetika : Jurnal Ilmu Sastra

Vol. V No. 2, Desember 2017
DOI $10.22146 /$ poetika.30937

ISSN 2338-5383 (print) ; 2503-4642 (online)

says, shaking that insolent head of hers. I can smell it in the air. They're either going to kill us, or ship us all off.' (Kakmi, 2008:46)

Hampir semua kekerasan yang diterima kaum Yunani ditampilkan melalui tokoh perempuan di dalam Mother Land, dan jika dilihat dengan teliti memang ada dua tokoh perempuan yang sangat ditonjolkan di dalam novel ini, yaitu Galatea sebagai tokoh ibu dan Athena wanita yang lebih tua yang ia sukai sewaktu kecil. Dua tokoh ini yang banyak menjadi representasi atas penindasan yang dilakukan oleh kaum Turki, meskipun ada bentuk perlawanan yang dilakukan, tetapi hal itu malah membenarkan bahwa mereka berada pada posisi inferior dan kaum mereka berada di bawah bayang -bayang Turki.

\section{Kesimpulan}

Berdasarkan pembahasan di atas, dapat disimpulkan bahwa memori traumatis Dmitri Kakmi dalam penulisan novel Mother Land dibentuk oleh transmisi familial dan transmisi affilial. Dalam transmisi familial, Kakmi mendapatkan memori masa lalu tentang Turki dan Yunani, sebelum, saat, dan pasca Armenian Genocide yang diterimanya dari generasi pertama, generasi kedua, dan generasi sezaman. Memori dari generasi pertama diperoleh Kakmi melalui kakek dan neneknya. Memori masa lalu dari generasi kedua diperoleh Kakmi melalui orang tua, bibi, dan pamannya. Memori masa lalu dari generasi sezaman diperoleh Kakmi dari adik perempuannya. Dalam transmisi affilial, Kakmi sebagai anak serta agen sejarah yang berinteraksi dengan dunia luar juga menerima memori masa lalu tentang Turki dan Yunani. Be- 
berapa memori mendukung apa yang Kakmi dapatkan dari narasi keluarga dan sebagian lagi bertentangan. Transmisi affilial tersebut dimediasi oleh peninggalan-peninggalan masa lalu seperti foto keluarga, musik yang membawa pesan tentang masa lalu dan benda-benda masa lalu yang menyimpan kenangan antara kaum Turki dan Yunani. Selain itu, transmisi secara affilial juga diterima Kakmi melalui orang-orang di sekitar seperti teman sebaya, masyarakat, dan guru.

Dalam proses transmisi, transmisi gender memainkan peran dari siapa dan kepada siapa transmisi yang kuat terjadi serta narasi apa yang diturunkan sebagaimana proses transmisi memori yang terjadi pada Kakmi. Pada novel Mother Land, pentransmisi yang paling berpengaruh adalah ayah dan kakek kepada Kakmi, di mana narasi yang diturunkan sangat jelas, selalu tentang Turki dan Yunani, yang kemudian ditarik hingga pembantaian yang terjadi saat perang dunia pertama di masa lalu yaitu Armenian Genocide, pembantaian besar-besaran yang dilakukan oleh kaum Turki terhadap kaum Yunani. Di sinilah gender menawarkan posisi Kakmi sebagai receiver, ayah dan kakek sebagai transmitter yang dominan serta narasi yang kuat tentang Turki dan Yunani yang ditransmisikan kepada Kakmi. Peran gender dalam proses transmisi memori inilah yang kemudian mengungkapkan adanya Father-son transmission, di mana transmisi yang kuat terjadi antara ayah dan anak laki-laki.

\section{Perjalanan kembali (returning journey)} merupakan salah satu bentuk identifikasi yang dilakukan Kakmi untuk menemukan trace atau jejak masa lalu yang berhubungan dengan Yunani ataupun Turki, tentang Armenian Genocide, baik sebelum, saat perang, maupun pascaperang dunia. Kakmi melakukan proses autentikasi yang mana nantinya, apa yang diceritakan di dalam novel tentang Turki maupun Yunani memiliki keterkaitan dengan kenyataan sebagai pembenaran terhadap apa yang ia ceritakan. Ada dua identifikasi yang dilakukan oleh Kakmi, yaitu identifikasi intergenerasional dan identifikasi intragenerasional. Identifikasi secara intergenerational, yaitu bentuk identifikasi vertikal yang didapat dalam ruang lingkup keluarga dari generasi yang hidup sebelum Kakmi. Identifikasi intergenerasional yang paling dominan didapat dari Ayah, karena ayah Kakmi satusatunya saksi mata pada masa lalu yang masih hidup hingga saat ini, sedangkan identifikasi intragenerasional adalah bentuk identifikasi horizontal yang membuat posisi Kakmi sebagai post-generation lebih terbuka dengan dunia luar. Bentuk identifikasi intragenerasional di dapat dari tempat-tempat yang menyimpan memori masa lalu, seperti barang -barang yang ditemukan masih ada hingga kini, foto keluarga dan musik juga menjadi salah media penting yang menjembatani masa kini dan masa lalu yang mana hal tersebut membantu Kakmi dalam memahami narasi masa lalu yang ia terima.

Dalam proses identifikasi tentu ada narasi ataupun kenyataan yang berbeda tentang Turki dan Yunani yang diterima oleh Kakmi selama ini. Pada tahapan inilah Kakmi melakukan proses seleksi terhadap narasi Turki dan Yunani mana yang akan dimunculkan dan mana yang akan dibungkam. Di sini lah trauma masa lalu yang 
diterimanya memainkan peran dalam proses seleksi, di mana Turki selalu direkatkan sebagai image yang kejam dan beringas. Pemberian image yang konsisten juga dilakukan Kakmi terhadap Yunani, di mana Yunani selalu digambarkan sebagai yang tertindas dan tidak bersalah. Ada beberapa bagian di mana kaum Turki dimunculkan sebagai "yang baik" yang direpresentasikan oleh tokoh Sinan dan beberapa tokoh lain yang dimunculkan di dalam novel, tetapi ada narasi setelahnya yang menghancurkan narasi yang di awal, bahkan ini merupakan cara mempertegas dan menggeneralisasi bahwa semua kaum Turki licik dan kejam.

Selanjutnya, yaitu proses repetisi. Repetisi dilakukan di dalam novel sebagai bentuk penegasan terhadap Turki dan Yunani. Kakmi memunculkan bentuk dikotomi yang sangat jelas di mana Turki digambarkan sebagai icon of destruction, dan Yunani sebagai yang tertindas, tidak bersalah, dan tersubordinasi. Narasi tentang kedua kaum baik Turki maupun Yunani direpetisi terus-menerus dan berulang-ulang. Hal ini pun membuat konstruksi gender yang terdapat di dalam novel Mother Land terlihat jelas, di mana Turki ditampilkan sangat mendominasi dan byper-masculine, mereka bukan hanya menguasai tanah kelahiran tetapi juga peraturan-peraturan yang merugikan kaum Yunani. Kekerasaan yang dilakukan terhadap kaum Yunani pun beragam, baik fisik maupun mental, baik secara eksplisit maupun implisit. Turki diperlihatkan sebagai supra buman evil, yang sangat maskulin, sedangkan feminization dilakukan terhadap kaum Yunani sebagai kaum yang tidak bersalah dan diinfantilisasi.

\section{Daftar Pustaka}

Hoffman, Eva. 2012. After such Knowledge: Memory, History, and the Legacy of the Holocaust. New York: Public affair.

Kakmi, Dmetri. 2008. Mother Land. Australia: Tower Books.

Kohler, Sandra. 2013. Transgenerational Trauma in the Novels of Julia Franck and Tanja Dückers. Chicago: University of Illinois.

Faruk. 2012. Metode Penelitian Sastra. Yogyakarta: Pustaka Pelajar.

G. Mai. 2009. An Exploration of The Intergenerational Transmission of Historical Trauma in Vietnamese Americans. San Francisco: California Institute of Integral Studies.

Hirsch, Marianne. 2012. Family Frame: Photography,

Narrative, and Postmemory. Cambridge,

Massachussets: Harvard University Press.

Hirsch, Marianne. 2012. The Generation of Postmemory: Writing and Visual Culture After Holocaust. New York: Columbia University Press.

Hirsch, Marianne. 2008. "Past Life: Postmemory in Exiled: European/American Perspective" Poetics Today 29:1, (Spring 2008): 103-128.

Hoffman, Eva. 2012. After such Knowledge: Memory, History, and the Legacy of the Holocaust. New York: Public Affair.

Kumalasari, Isti. 2016. The Book Thief Karya Markus Zuzak: Sebuah Kajian Postmemory. Tesis. Yogyakarta: Fakultas Ilmu Budaya Universitas Gadjah Mada.

Winter, Jay. 2008. America and The Armenian Geno- 
Poetika : Jurnal Ilmu Sastra

Vol. V No. 2, Desember 2017
DOI 10.22146/poetika.30937 ISSN 2338-5383 (print) ; 2503-4642 (online)

cide of 1915. Cambridge: Cambridge University Press.

\section{Sumber Wawancara}

Kakmi, Dmetri. 2017. Melbourne, Australia, November 03. 